David Lester

The "I" of the Storm: Understanding the Suicidal Mind 



\section{David Lester}

\section{The "I" of the Storm}

Understanding the Suicidal Mind

Managing Editor: Aneta Przepiórka 
Published by De Gruyter Open Ltd, Warsaw/Berlin

\section{(cc) BY-NC-ND}

This work is licensed under the Creative Commons Attribution-NonCommercial-NoDerivs 3.0 license, which means that the text may be used for non-commercial purposes, provided credit is given to the author. For details go to http://creativecommons.org/licenses/by-nc-nd/3.0/.

(C) 2014 David Lester

ISBN: 978-3-11-037481-0

e-ISBN: $978-3-11-037482-7$

Bibliographic information published by the Deutsche Nationalbibliothek

The Deutsche Nationalbibliothek lists this publication in the Deutsche Nationalbibliografie; detailed bibliographic data are available in the Internet at http://dnb.dnb.de.

Managing Editor: Aneta Przepiórka

www.degruyteropen.com

Cover illustration: (C) ThinkStock/andreusK 